\title{
Gastritis and gastric campylobacter-like organisms in patients without peptic ulcer
}

\author{
P. Sethi ${ }^{1 *}$, A.K. Banerjee ${ }^{2}$, D.M. Jones ${ }^{1}$, J. Eldridge ${ }^{1}$ and D. Hollanders ${ }^{1}$ \\ ${ }^{\prime}$ University Hospital of South Manchester, Manchester M20 8LR and ${ }^{2}$ Bolton General Hospital, Minerva Road, \\ Farnworth, Bolton, Lancs, UK.
}

\begin{abstract}
Summary: Gastric biopsy specimens were obtained from 83 patients without peptic ulcer disease and analysed histologically. Culture and serological studies were done on the last 64 patients. The patients were divided into two age groups (young and old groups.) In 34 patients with chronic superficial gastritis, gastric campylobacter-like organisms (GCLO) were identified histologically in $91 \%$ and grown on culture in $88 \%$ : antibody to GCLO was detected in $81 \%$. No age-related difference in the prevalence of the organism was demonstrated. In the 23 patients with atrophic gastritis (all elderly), presence of the organisms appeared to be related to the presence of an inflammatory cell infiltrate into the gastric mucosa.

These figures for the prevalence of the organism in this selected group of patients are similar to those reported in previous studies of unselected patients which included those with peptic ulcer. This suggests that GCLO is unlikely to be causally related to peptic ulcer.
\end{abstract}

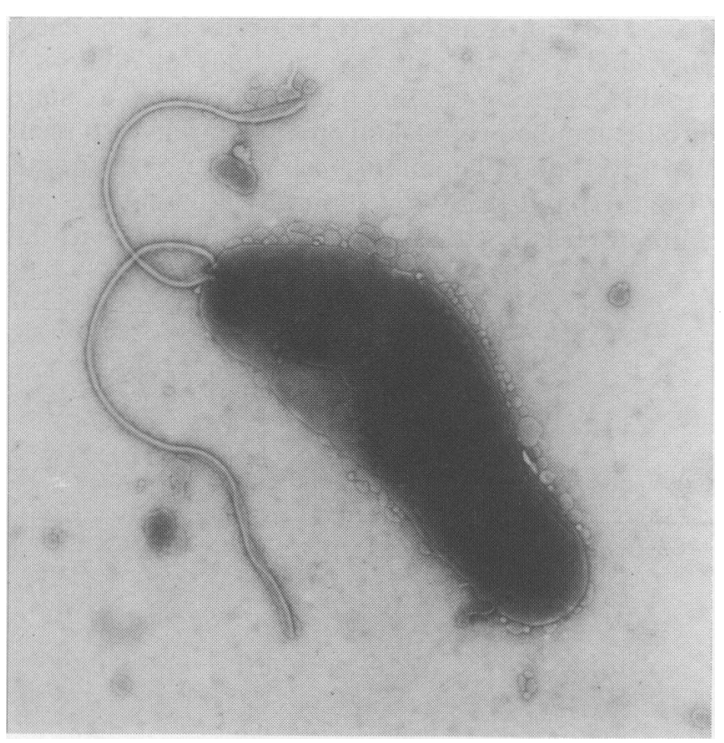

Figure 1 Electron micrograph of a negatively stained preparation of a human GCLO from cultured material. Stained with PTA pH 6.5, magnification $\times 32,000$.

*Correspondence and present address: P. Sethi, M.R.C.P. (U.K.), Department of Geriatric Medicine, Ladywell Hospital, Salford M5 2AA, UK.

Accepted: 25 November 1986

\section{Introduction}

Warren \& Marshall in $1983^{1}$ reported the presence of gastric campylobacter-like organism (GCLO) on the gastric mucosa and showed that the organism is associated with histological gastritis. Subsequently, their findings have been confirmed in various studies, both prospective ${ }^{2,3}$ and retrospective. ${ }^{4}$ It has been suggested that the organism may have a causative role in the pathogenesis of peptic ulcer ${ }^{5}$ but this has not been confirmed by Koch's criteria.

GCLO is a spiral Gram-negative organism with up to five unipolar flagellae living in the mucous layer of the gastric surface (Figure 1). It is morphologically distinct from Campylobacter jejuni and is as yet bacteriologically unclassified.

Most of the previous studies have included patients with and without peptic ulcer. This study was designed to investigate the presence of the organism in patients without peptic ulcer or reflux oesophagitis and to compare the prevalence in young and elderly patients.

\section{Patients and methods}

\section{Patients}

Gastric biopsy specimens were obtained from the antrum and mid-greater curve of 83 patients without endoscopic evidence of peptic ulcer disease or reflux oesophagitis. Two age groups were studied, 20 to 50 years (young group, mean age 37 years, 16 females, 23 
males) and more than 70 years (elderly group, mean age 77 years, 21 females, 23 males). Indications for gastroscopy were similar in the two groups - upper gastrointestinal symptoms accounting for $90 \%$ of the referrals in the younger, and $80 \%$ in the older group of patients. Iron deficiency anaemia with or without dyspepsia was an indication in $15-20 \%$ of the elderly population. Patients with a history of peptic ulcer disease, gastric surgery, pernicious anaemia or those currently using non-steroidal anti-inflammatory agents, steroids or ulcer healing drugs were excluded.

\section{Methods}

Histology Samples were orientated on filter paper, fixed in buffered formaldehyde and embedded in JB4 resin (Polysciences Inc). Sections were stained with haematoxylin and eosin. Histological classification of cases into groups consisting of normals, chronic superficial gastritics and atrophic gastritics was accomplished according to the criteria of Whitehead. ${ }^{6}$ Sections were scanned for the presence of GCLO in the mucous layer adjacent to the gastric epithelium using a $\times 40$ objective lens.

Culture and serology Culture and serological studies were carried out in the last 64 consecutive patients enrolled in the study, according to the methods described previously, ${ }^{2}$ Antibody to GCLO was measured by complement fixation test (using a sonicate of the organism as antigen), and enzyme-linked immunosorbent assay (ELISA).

\section{Results}

Normal histology (Table I)

Of the 83 patients, $26(31 \%)$ were histologically normal, $9(20.5 \%)$ in the elderly group, $17(43.6 \%)$ in young group). GCLO was grown on culture in only one of these and all cases were negative for antibody to the organism.

\section{Chronic superficial gastritis (Table I)}

Of the 34 patients in this group, the organism was identified histologically in 31 (91\%). Twenty-six of the 34 had culture and serology performed $-88 \%$ were culture positive and antibody was detected in $80 \%$. There was no significant difference between culture and antibody positivity in the two age groups studied.

Atrophic gastritis (Table I)

All patients with atrophic gastritis were from the elderly group and were negative for gastric parietal cell and intrinsic factor antibody. Derangement of glandular architecture, thinning of the mucosa with metaplasia, was noted in the antral biopsies in some cases only, and both the antrum and body in others. variable degree of chronic inflammatory cell exudate into the lamina propria and epithelium was also seers In 4 cases, no inflammatory cell infiltrate was found (Table II) and these 4 were negative on culture and antibody was not detected. Of the 13 cases with an

Table I Histology (83 patients), culture and serology (64 patients) results in patients without peptic ulcer

\begin{tabular}{|c|c|c|c|c|c|c|}
\hline \multirow{3}{*}{$\begin{array}{l}\text { Histology } \\
\text { Normal gastric histology }\end{array}$} & \multirow{2}{*}{ Age group } & \multirow{2}{*}{$\begin{array}{l}\text { GCLO seen } \\
\text { (microscopy) }\end{array}$} & \multirow{2}{*}{$\begin{array}{c}\text { GCLO grown } \\
\text { (culture) }\end{array}$} & \multirow{2}{*}{$\begin{array}{c}\text { Antibody } \\
C F T\left(>2^{*}\right)\end{array}$} & \multicolumn{2}{|c|}{ Positive ELISA } \\
\hline & & & & & $\operatorname{Ig} G(>2)$ & $\operatorname{Ig} M(>2)$ \\
\hline & young & & & & & \\
\hline & $\begin{array}{l}17 \\
\text { elderly }\end{array}$ & $0 / 17$ & $0 / 13$ & $0 / 13$ & $0 / 13$ & $0 / 13$ \\
\hline & 9 & $0 / 9$ & $1 / 8$ & $0 / 8$ & $0 / 8$ & $0 / 8$ \\
\hline \multirow[t]{3}{*}{ Chronic superficial gastritis } & young & & & & & \\
\hline & $\begin{array}{c}22 \\
\text { elderly }\end{array}$ & $20 / 22$ & $16 / 17$ & $14 / 17$ & $14 / 17$ & $3 / 17$ \\
\hline & 12 & $11 / 12$ & $7 / 9$ & $7 / 9$ & $7 / 9$ & $1 / 9$ \\
\hline \multirow[t]{3}{*}{ Atrophic gastritis } & young & & & & & \\
\hline & nil & - & - & 一 & - & - \\
\hline & 23 & $10 / 23$ & $9 / 17$ & $12 / 17$ & $12 / 17$ & $1 / 17$ \\
\hline
\end{tabular}

*Complement fixation test - reciprocal titres 
Table II Culture and antibody status to GCLO in 17 patients with atrophic gastritis

\begin{tabular}{lcc}
\hline & $\begin{array}{c}\text { Atrophic gastritis } \\
\text { with inflammatory } \\
\text { response into gastric } \\
\text { mucosa (13) }\end{array}$ & $\begin{array}{c}\text { Atrophic gastritis } \\
\text { without inflammatory } \\
\text { response into gastric } \\
\text { mucosa (4) }\end{array}$ \\
\hline $\begin{array}{l}\text { Culture positive } \\
\text { CFT positive* } \\
\begin{array}{c}(>2) \\
\text { ELISA positive }\end{array} \\
\begin{array}{l}(>2) \\
\text { m }\end{array}\end{array}$ & 9 & 0 \\
\hline
\end{tabular}

* reciprocal titre

inflammatory response into the gastric mucosa - 9 $(69 \%)$ were culture positive and $12(92 \%)$ had antibody in the serum.

Table III shows that of the 33 patients who had antibody, $29(88 \%)$ were culture positive, all patients with histological gastritis were positive for antibody.

\section{Discussion}

This study shows that in patients without peptic ulcer, GCLO was identified histologically in $41 \%$, grown on culture from gastric biopsies in $51.5 \%$ and an antibody response detected in $40 \%$. The organism was grown on culture in $88 \%$ of the patients with chronic superficial gastritis and an antibody response seen in $81 \%$. These figures are similar to those reported previously and support the association of the organism with histological gastritis. None of the patients studied had peptic ulcer disease; therefore, if the organism does have an aetiological role, it is with gastritis rather than peptic ulcer in these cases.

Of the 33 patients who had antibody, $88 \%$ had the

\section{References}

1. Warren, J.R. \& Marshall, B.J. Unidentified curved bacilli on gastric epithelium in active chronic gastritis. Lancet 1983, i: $1273-1275$.

2. Jones, D.M., Lessells, A.M. \& Eldridge, J. Campylobacter-like organisms on the gastric mucosa; culture, histological and serological studies. J Clin Pathol 1984, 37: 1022-1026.

3. McNulty, C.A.M. \& Watson, D.M. Spiral bacteria of the gastric antrum. Lancet 1984, i: 1068-1069.
Table III Gastric mucosal culture and histology results in 64 patients with positive and negative tests for antibody to gastric campylobacter-like organism

\begin{tabular}{lcccc}
\hline & $\begin{array}{c}\text { Culture } \\
\text { positive }\end{array}$ & $\begin{array}{c}\text { Culture } \\
\text { negative }\end{array}$ & Gastritis & $\begin{array}{c}\text { Normal } \\
\text { histology }\end{array}$ \\
\hline $\begin{array}{l}\text { Antibody } \\
\text { positive (33) } \\
\begin{array}{l}\text { Antibody } \\
\text { negative (31) }\end{array}\end{array}$ & 29 & 4 & 33 & 0 \\
\hline
\end{tabular}

organism grown from gastric biopsies and all 33 had histological gastritis. It therefore appears that the presence of antibody to GCLO has predictive value both for the presence of the organism in the stomach and histological gastritis.

The number of elderly patients in the atrophic gastritis group is small and therefore precludes any conclusions being drawn. However, the lack of antibody and the absence of the organism in the stomachs of the patients in this group who did not have an inflammatory exudate into the gastric mucosa, may imply an association between the organism and the local inflammatory response, If so, is the inflammatory response secondary to the organism, or do the inflammatory cells produce changes in the gastric 'internal milieu' allowing the organism to colonize the stomach? This basic question is as yet unanswered.

\section{Acknowledgements}

Our thanks to Dr S. Bannerjee for his help with histological analysis and Miss S. Whitworth for secretarial assistance.

4. Rollason, T.P., Stone, J. \& Rhodes, J.M. Spiral organisms in endoscopic biopsies of the human stomach. $J$ Clin Pathol 1984, 37: 23-26.

5. Marshall, B.J. \& Warren, J.R. Unidentified curved bacilli in the stomach of patients with gastritis and peptic ulceration. Lancet 1984, i: 1311-1314.

6. Whitehead, R. In Mucosal Biopsy of the Gastro-intestinal Tract, 2nd Edition, W.B. Saunders, London, 1979, pp. 20-32. 